This is an author produced version of a paper published in Journal of Vegetation Science. This paper has been peer-reviewed and is proofcorrected, but does not include the journal pagination.

Citation for the published paper:

Ranius, T., Johansson, P., Berg, N., Niklasson, M. (2008) The influence of tree age and microhabitat quality on the occurrence of crustose lichens associated with old oaks. Journal of Vegetation Science.

Volume: 19 Number: 5, pp 653-662.

http://dx.doi.org/10.3170/2008-8-18433

Access to the published version may require journal subscription.

Published with permission from: Opulus Press

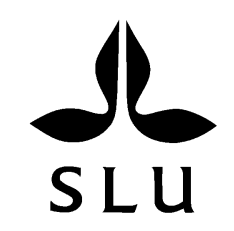

Epsilon Open Archive http://epsilon.slu.se 
Should be cited as: Ranius, T., Johansson, P., Berg, N., Niklasson, M. (2008) The influence of tree age and microhabitat quality on the occurrence of crustose lichens associated with old oaks. Journal of Vegetation Science 19: 653-662, 2008

doi: 10.3170/2008-8-18433, published online 2 April 2008

Available at: http://onlinelibrary.wiley.com/journal/10.1111/(ISSN)1654-1103

\title{
The influence of tree age and microhabitat quality on the occurrence of crustose lichens associated with old oaks
}

\author{
Ranius, Thomas1*; Johansson, Per1; Berg, Niclas1 \& Niklasson, Mats2 \\ 1 Swedish University of Agricultural Sciences, Department of Ecology, P.O. Box 7044, SE-750 07 Uppsala, Sweden; \\ 2Swedish University of Agricultural Sciences, Southern Swedish Forest Research Centre, P.O. Box 49, SE-230 53 \\ Alnarp, Sweden; \\ *Corresponding author; Fax+46 18672890; E-mail thomas.ranius@ekol.slu.se
}

\begin{abstract}
Questions: How do tree age, microhabitat characteristics and epiphytic competitors affect the occurrence of crustose lichens associated with old oaks? How do microhabitat characteristics and microclimate affect the cover of competitors (bryophytes and macrolichens)? How do microhabitat characteristics correlate with microclimatic variables?
\end{abstract}

Location: Southeast Sweden.

Methods: Eight crustose lichen species were surveyed on 165 Quercus robur trees, 17-478 years old, at three study sites. The occurrence patterns of these species were examined at two spatial scales: among trees and within trees. Occurrence patterns within trees were examined in $10 \mathrm{~cm} \times 10 \mathrm{~cm}$ plots at all four cardinal aspects at different heights from 0.5 to $4.5 \mathrm{~m}$ above the ground.

Results: At the tree level, age-related factors were the most important predictors of species occurrence. All species were more frequent on trees $>100$ years than on younger trees. At the plot level, the frequency of occurrence increased with increasing bark crevice depth. The frequencies of all study species decreased with increasing cover of bryophytes. Bryophytes were in turn more frequent in plots that were exposed to rainwater and showed a low evaporation rate. Patches most exposed to rainwater were directed upwards, and the lowest evaporation rates occurred on the northern side of the trunks.

Conclusions: For many crustose lichens the association with old oak trees seems at least partly to depend on their preference for the deep bark crevices that only occur on old trees. Trees represent epiphyte habitat patches that differ in size due to within-tree variability in habitat quality, such as bark crevice depth and microclimate. This study shows that variability at a finer scale, within habitat patches, contribute to explain species occurrence patterns at habitat patch level.

Keywords: Bark crevice; Epiphyte; Evaporation; Habitat patch size; Microclimate; Quercus robur; Sun exposure. Nomenclature: Santesson et al. (2004). 


\section{Introduction}

The original approach to metapopulation modelling assumed the occurrence of networks of similar discrete patches, and ignored the quality of individual patches (Levins 1969). Consequently, habitat quality has been described as the missing third parameter in metapopulation dynamics (Thomas et al. 2001). With increasing awareness of its importance, habitat quality has been incorporated into more recent metapopulation models (e.g. Hanski \& Ovaskainen 2000; Akçakaya et al. 2004). However, it is often difficult to examine species’ habitat requirements and measure the quality of habitat patches. One example is given by epiphytes, for which individual trees can be regarded as habitat patches potentially supporting local populations (Snäll et al. 2005). For epiphytic cryptogams, tree size is often used as a predictor of community structure and species occurrence (Uliczka \& Angelstam 1999; Johansson \& Ehrlén 2003; Kantvilas \& Jarman 2004; Löbel et al. 2006). However, it is difficult to interpret habitat requirements from simple observations of relationships with tree size or tree age. This is because at least three different interrelated factors are involved (cf. Snäll et al. 2003; Kantvilas \& Jarman 2004; Johansson et al. 2007). First, as trees grow, availability of different microhabitats changes. Second, as trees age the time available for colonisation increases. Third, as tree size increases the probability of colonisation increases because the surface area available for colonisation increases. These factors are difficult to disentangle; for instance, an observed positive relationship between occurrence and bark crevice depth does not necessarily reflect habitat quality, but may, at least in part, be an effect of tree size (Löbel et al. 2006) or the tree’s age as a suitable habitat.

Besides tree age, factors such as light and water supply can explain epiphyte variation among, as well as within, trees. These factors are in turn affected by the surrounding vegetation, bark condition, aspect, wind exposure, height above ground, and trunk inclination (e.g. Billings \& Drew 1938; Hale 1955; Barkman 1958; Bates 1992; Moe \& Botnen 2000; Loppi \& Frati 2006). Light and water supply also affect interactions among epiphytes; on the upper sides of leaning tree trunks, fast growing mosses can become abundant while on the dry lower sides only a few crustose lichens are able to grow (Billings \& Drew 1938; Barkman 1958; Kenkel \& Bradfield 1986; Bates 1992; Kuusinen 1994).

In Europe, a large proportion of the oldest trees are Quercus robur, partly because this species is naturally very long-lived and partly because it has tended to be retained during management. Therefore, this is a keystone species for biodiversity associated with ancient trees, including lichens (Rose 1976). In Sweden, ca. 300 lichen species are known to inhabit oak trees. Many lichens found on old oaks are crustose species that today are rare and red-listed. They are assumed to depend on the oak trees' great age and deeply fissured rough bark (Hultengren et al. 1997; Thor \& Arvidsson 1999); however, no quantitative studies of epiphytes on oaks are available to support these assumptions.

In this study, presence/absence of eight crustose lichen species on 165 oaks was assessed and their relationship with tree age and other characteristics of the trees were studied. To examine the effects of microhabitat quality, we also studied vertical and horizontal occurrence of lichens on the 30 trees supporting the greatest number of target species. Because bryophytes and macrolichens may be important competitors with crustose lichens, we examined the effect of their cover on the target lichen species. We also examined how the microhabitat variables affected the cover of bryophytes and macrolichens. For a subset of ten trees, we estimated variability in water availability and evaporation rate within trees. The aim was to examine how microhabitat 
quality and microclimate affect the epiphytes and if direct measures of the microclimate were related with characteristics that often are used as indirect measures of microclimate.

\section{Methods}

\section{Study sites and trees}

The survey was conducted at three sites (Brokind, Sundsbro and Bjärka-Säby) in southeast Sweden (around $58^{\circ} 15^{\prime} \mathrm{N}, 15^{\circ} 45^{\prime} \mathrm{E}$ ), situated 6-15 km from each other. The Brokind and Sundsbro sites each consisted of a single oak pasture, while the Bjärka-Säby site consisted of three subsites, situated 1-3.5 km from each other. The sites were selected because of their high density of old oaks, and therefore they were expected to host comparatively large source populations of our study species (Ranius et al. 2001). The sites were grazed by cattle and most trees were free-standing or in semi-open situations; no trees were heavily affected by forest regrowth.

Lichens were surveyed on 165 oaks, which were selected in a study of tree hollows (T. Ranius, M. Niklasson $\&$ N. Berg, subm.). Similar numbers of trees from each of the following categories were selected: (1) young trees without hollows; (2) older trees without hollows; and hollow trees with (3) small entrance holes, (4) intermediate entrance holes and (5) large entrance holes. This implies that all age classes were represented among the studied trees, but not necessarily in the same proportion as in the entire oak populations. All trees, except two trees that recently had died, were alive at the time of the study.

\section{Study species and lichen survey at tree level}

For this study we selected eight crustose lichen species, of which all except Chrysothrix candelaris were of high conservation interest because they were in use as indicator species or were included in the Swedish Red List (Nitare 2005; Gärdenfors 2005; Table 1). At the study sites, oaks were by far the most important substrate for all target species, since pedunculate oak was the dominant species among old trees.

For each tree, tree characteristics were estimated (Table 2), and the cover of each study species on the trunk up to a height of $2 \mathrm{~m}$ was classified as follows: absent (0), cover $<1 \mathrm{dm} 2$ (1), 1-5 dm2 (2), and $>5 \mathrm{dm} 2$ (3). To estimate tree age, from each tree two to four increment cores were taken at a height of 0.5-1.3 m. The cores were cross-dated using the classical memory dating method based on conspicuous pointer years (e.g. Stokes \& Smiley 1968). For 95 of the trees, the best increment core reached a point less than $25 \mathrm{~mm}$ from the pith. Their age was estimated by counting the annual rings, and when the pith was missed we estimated the distance to pith by fitting a transparent plastic with imprinted concentric circles on the sample. The number of rings missed was estimated by assuming the growth rate being equal with the three innermost rings on the core. For the remaining 70 trees, the age, $a$, was estimated using the following equation:

$a=c+r /(k \times g)(1)$

where $c$ is the number of annual rings in the longest increment core, $r$ is the radius of the hollow (i.e. distance from the innermost tree ring present to the geometric midpoint), $g$ is the growth rate of the innermost ten years of the increment core, and $k$ is a parameter that depends on how quickly the annual growth rate decreases with tree age. 
A function that predicts $k$ was obtained by using tree ring data from the 95 trees with intact trunks. From these trees, we simulated hollow trees by assuming the inner part of the trunk to be absent. The absent inner parts corresponded to multiples of ten annual rings. We weighted the data set of simulated trees to obtain the same distribution of trunk diameters and core lengths as among the 70 trees we wanted to age. For each simulated tree, we calculated the true value of $k$ from the intact annual rings. The value of $k$ (or the logarithm of $k$ ) was used as dependent variable in a multiple linear regression model. As independent variables we used characteristics that were available for all trees (trunk diameter, radius of the hollow, growth rate of the inner ten years, and bark crevice depth). By including both the independent variables and their logarithms, and successively remove nonsignificant $(p<0.05)$ variables, we obtained the following function:

$k=1.66-0.90 \ln (g)(2)$

where $g$ is the growth rate (in mm/year) of the inner ten rings of the increment core. For the simulated hollow trees, there was a strong correlation between the real age and the age estimated by the function $\left(R_{2}=0.839\right)$. When Eqs. (1) and (2) were used to estimate tree age, the piths were assumed to be at the geometric centres of the trunks.

\section{Lichen survey and microclimate at sample plot level}

Based on results from the survey at the level of individual trees, we selected at each of the three sites the ten trees on which the most study species were noted. The age of the 30 study trees was between 183 and 447 years (mean: 334 years), and the diameter between 68 and $175 \mathrm{~cm}$ (mean: $118 \mathrm{~cm})$. For these trees, we defined $10 \mathrm{~cm}$ $\times 10 \mathrm{~cm}$ sample plots at all cardinal points $(\mathrm{N}, \mathrm{W}, \mathrm{E}$, and $\mathrm{S})$ and at five different heights $(0.5,1.5,2.5,3.5$, and $4.5 \mathrm{~m}$ ), i.e. in total 20 plots per tree. For each plot we recorded the presence/absence of the study species and measured habitat characteristics (Table 2). At one site, Sundsbro, we used the ten trees to examine how microclimate affected the epiphytes, and to analyse the extent to which easily measured habitat characteristics actually reflected microclimate. In the $10 \mathrm{~cm} \times 10 \mathrm{~cm}$ sample plots at these ten trees we measured two microclimate variables: evaporation rate in sunny weather and exposure to rainwater.

The evaporation rate was measured by placing a water-saturated cellulose sheet (a $40 \mathrm{~mm} \times 40 \mathrm{~mm} \times 2 \mathrm{~mm}$ Wettex sheet) in each sample plot for three hours. Under the cellulose sheet, we placed a plastic sheet to avoid loss of water from the sheet to the trunk. The weight of the cellulose sheet was recorded before and after the treatment. Measurements were carried out in sunny conditions with no wind (09.10.2006, at 11.50 - 17.30, shade temperature $14{ }^{\circ} \mathrm{C}$ ). The evaporation, $e$, was estimated from the reduction in the weight of the cellulose sheet as follows:

$e=t /(s-d)(3)$

where $t$ is the decrease in weight during the treatment, $s$ is the weight at the start of the treatment and $d$ the dry weight.

The degree of exposure to rainwater was measured by setting the same cellulose sheets (dry) in the sample plots during rainfall. The increase in weight after two hours was divided by the weight of the dry sheets. The experiment was conducted at noon when there was no wind. For four trees data were collected on 20 October 
and for six trees on 23 October. The difference in weather between these occasions did not matter, as we did not make any between-tree comparisons; in statistical tests we used the microclimate variables to rank the plots on individual trees.

\section{Statistical analyses}

At the tree level, statistical analyses were conducted for the six lichen species found on at least five oaks, and at the plot level for the four species found in at least five plots. Both at the tree level and the sample plot level, the occurrence (presence or absence) of the study species was analysed in relation to the measured tree characteristics using multiple logistic regressions. Statistical models were obtained by successively eliminating nonsignificant ( $p>0.05$, log likelihood ratio significance) variables from a model that originally contained all predictor variables. However, three variables were included in all final models regardless if they were statistically significant or not: site (at the tree level), tree identity and connectivity (at the sample plot level). Site was included to remove the variation among sites, and tree identity to remove the variation among trees, since the aim was to test the significance of variables at the tree level, and sample plot level, respectively. Connectivity was included to account for spatial autocorrelations of species occurrence on individual trunks. Correlations among predictor variables were assessed with Spearman’s correlations (Sokal \& Rohlf 1995).

Multiple linear regression models were obtained with habitat and microclimate variables as predictor variables, and species richness of the study species, macrolichen cover, and bryophyte cover as dependent variables. This was done by successively eliminating non-significant $(p>0.05)$ predictors from a full model (i.e. a model that originally contained all predictors). Finally, to elucidate the extent to which habitat variables reflect microclimate, we analyzed the relationships (one pair of variables at a time) between the microclimate variables and microhabitat variables using Spearman’s correlations.

SPSS 13.0 was used for all statistical analyses.

\section{Results}

\section{Lichen occurrence at tree level}

All eight study species were more frequent on trees $>100$ years old than on younger trees (Fig. 1). Three of the five variables that were statistically significant predictors of presence/absence at the tree level (diameter, age, and bark crevice depth; Table 3) were strongly positively correlated with each other (Table 4). For five species out of six there were significant, positive relationships with at least one of the age-related variables. Only for one species, Chrysothrix candelaris, occurrence was significantly related with other variables: positively with shading and negatively with stem inclination (Table 3).

\section{Lichen occurrence at sample plot level}

At the $10 \mathrm{~cm} \times 10 \mathrm{~cm}$-sample plot level, the most important variable for predicting species presence/absence was the cover of bryophytes (Table 5). Increasing bryophyte cover decreased the probability of occurrence of all target species (Fig. 2), while macrolichen cover had a much weaker influence. The second most important variable was bark crevice depth, which had a positive effect on three species out of four (Table 5, Fig. 3). 
Furthermore, aspect had some effect; two species (Chrysothrix candelaris and Calicium adspersum) were significantly less frequent on the south-facing sides of the tree trunks (Table 5).

Inclination had a negative effect on Chaenotheca phaeocephala occurrence (Table 5). This means that sample plots with a positive inclination (the 'upper sides' of tree trunks) were less likely to host Chaenotheca phaeocephala than sample plots with negative inclination. For all species, the frequency of occurrence tended to peak at $1.5 \mathrm{~m}$, and was lower at both $0.5 \mathrm{~m}$ and at higher levels (Fig. 4). Bark crevices became deeper at lower levels of the trunk (Table 6),

For bryophytes and macrolichens, the relationship with bark crevice depth was negative, while it was positive for target species richness (Table 7). Bryophyte cover was significantly correlated with several variables associated with moist conditions. In contrast, cover of macrolichens was negatively correlated with the cover of shrubs, and the number of study species was negatively correlated with exposure to rainwater.

The exposure to rainwater was correlated with bark crevice depth $(-0.238, p=0.001)$ and inclination $(0.318$, $p<0.001)$. The evaporation rate was higher at south-facing plots $(0.212, p=0.003$, all tested using nonparametric Spearman's correlation).

\section{Discussion}

As expected, the frequency of occurrence of crustose lichens increased with tree age (Fig. 1). Based on tree-level data alone, it is however difficult to see if the higher frequencies on older trees are the result of a preference for trees with characteristics typical of old trees, or other factors. However, plot-level data strongly suggest that deep bark crevices are important, since the study species occurred more frequently on parts of the trunks with thedeepest bark crevices (Table 5, Fig. 3). Even when plots with a high cover of bryophytes were excluded from the analysis, a positive relationship between lichens and bark crevice depth remained (Fig. 3). One reason for this relationship could be that the microclimate is more suitable for lichens in the deepest part of the crevices. Another possible explanation is that the physical or chemical properties of coarse bark differ from those of smooth bark. This explanation is supported by studies of younger trees that have shown that chemical and physical properties of bark may change with bark thickness(Bates \& Brown 1981) or tree age (Gauslaa 1985), and that the chemical properties may affect the epiphyte species composition (Bates 1992). More studies on old oaks are required to elucidate the mechanisms underlying the differences in habitat quality between bark of different crevice depths.

South-facing sides of oak trunks are often described as hosting the largest number of lichen species (Lindblom \& Måreby 1989; Hultengren et al. 1997). In this study, no species were associated with south-facing sides of the tree trunks. Instead, two species, Calicium adspersum and Chrysothrix candelaris, were negatively correlated with south-facing sides (Table 5). In congruence with our results, Rydberg (1997) concluded that calicioid species in general were less common on south-facing sides of oak trunks, while on north-facing sides they were limited by overtopping by bryophytes and macrolichens.

At the sample plot level, bryophyte cover was the strongest variable affecting the occurrence of study species (Table 5). The bryophyte cover, in turn, seemed to be controlled by microclimate, especially water availability, as indicated by its correlations with aspect, inclination, evaporation and exposure to rain water (Table 7). These results are consistent with those of prior studies of epiphytes, which have also found that bryophytes dominate where water availability is high, for example on inclined trunk surfaces (Billings \& Drew 1938; Barkman 1958; 
Kenkel \& Bradfield 1986; Bates 1992; Kuusinen 1994; Moe \& Botnen 2000). Clearly, crustose lichens are negatively affected by bryophyte overgrowth, while the influence of macrolichens is much weaker. The difference may be due to the fact that bryophytes, when present, are much more dominant than macrolichens; both macrolichens and bryophytes occurred at $36 \%$ of the plots, but the mean cover of bryophytes was much higher than that of macrolichens (Table 2).

Microclimate is found to be important for the epiphytic flora. Therefore, it would be useful to identify indicator variables that are known to be strongly related to microclimate but easier to measure. Trunk inclination at plot level appears useful as an indirect measure of exposure to rainwater, because these two variables are correlated. Furthermore, in this study we verified that south-facing plots have the highest evaporation rates.

For none of the study species a statistically significant relationship with height on the trunk is found. This may be because the highest frequency of occurrence is at an intermediate height; all study species tend to be most frequent at a height of $1.5 \mathrm{~m}$ (Fig. 4). Vertical gradients in epiphyte species cover and composition that have been demonstrated in several previous studies (e.g. Hale 1952; Harris 1970; Bates 1992) may be the results of change in bark crevice depth and microclimate with height. In the trees we examined, bark crevices became deeper at lower levels (Table 6), and this might explain the tendency for lower frequencies above a height of $2 \mathrm{~m}$.

\section{Oaks as habitat patches harbouring specialised lichen species}

The red-listed lichen species surveyed in this study occurred mainly on trees > 200 years old. Hence, a large proportion of the trees in an oak pasture are unsuitable for these species because the trees are too young. Moreover, even if the age is sufficient for hosting these crustose lichens, habitat patch size may differ between trees due to variability of bark crevice depth on individual trees, which makes some parts of the trunk more suitable for lichen colonisation than others. Here we exemplify how this affects habitat patch size by estimating the area suitable for Calicium adspersum and Lecanographa amylacea on the 30 trees used for studying plot level occurrence. Calicium adspersum only occurred in sample plots where the bark crevice depth exceeded 20 $\mathrm{mm}$, while Lecanographa amylacea only occurred in four plots on a single tree, at all of which the bark crevice depth exceeded $60 \mathrm{~mm}$. All lichen species were more frequent when the bryophyte cover was low (Fig. 2). Assuming that $C$. adspersum requires $>20 \mathrm{~mm}$ bark crevice depth and $<30 \%$ bryophyte cover, all 30 trees examined at the plot level constituted suitable habitat patches. Among these trees, the proportion of suitable study plots varied between $45 \%$ and $90 \%$. For L. amylacea, only $27 \%$ of these trees were suitable given that > $60 \mathrm{~mm}$ bark crevices and $<30$ \% bryophyte cover are required. On the only trunk among the 30 that actually hosted the species, $40 \%$ of the area was suitable, while for the other trees, $5 \%$ - $25 \%$ was suitable. These findings show that the habitat patch size is not equal for all trees, nor is it only a simple function of trunk diameter, but it is dependent on the variability in habitat quality over the tree trunk.

Epiphytes have often been studied at the individual tree level. This seems to be a relevant scale for our study species, since we find strong relationships between their occurrence and several tree characteristics, but no significant differences in their frequencies of occurrence between sites (Table 1). However, even if the assumption that each tree represents a habitat patch potentially harbouring a local epiphyte population is useful (Snäll et al. 2003), our study shows that it is also useful to study variability at a finer scale, within habitat patches, as it contributes to explain species occurrence patterns at the tree level. 
Acknowledgements. Heidi Paltto made valuable comments on the manuscript. Financial support came from Formas (a grant to Thomas Ranius for the project 'Predicting extinction risks for threatened wood-living insects in dynamic landscapes') and Stiftelsen Eklandskapsfonden i Linköpings kommun (to Thomas Ranius).

\section{References}

Akçakaya, H.R., Radeloff, V.C., Mladenoff, D.J. \& He, H.S. 2004. Integrating landscape and metapopulation modeling approaches: viability of the sharp-tailed grouse in a dynamic landscape. Conservation Biology 18: 526-537.

Barkman, J.J. 1958. Phytosociology and ecology of cryptogamic epiphytes. Van Gorcum \& Comp., Assen, NL.

Bates, J.W. 1992. Influence of chemical and physical factors on Quercus and Fraxinus epiphytes at Loch Sunart, western Scotland: a multivariate analysis. Journal of Ecology 80: 163-179.

Bates, J.W. \& Brown, D.H. 1981. Epiphyte differentiation between Quercus petraea and Fraxinus excelsior in a maritime area of south west England. Vegetatio 48: 61-70.

Billings, W.D. \& Drew, W.B. 1938. Bark factors affecting the distribution of corticolous bryophytic communities. The American Midland Naturalist 20: 302-330.

Gärdenfors, U. 2005. The 2005 red list of Swedish species. ArtDatabanken, Sveriges Lantbruksuniversitet, Uppsala, SE.

Gauslaa, Y. 1985. The ecology of Lobarion pulmonariae and Parmelion caperatae in Quercus dominated forests in southwest Norway. Lichenologist 17: 117-140.

Hale, M.E. 1952. Vertical distribution of cryptogams in a virgin forest in Wisconsin. Ecology33: 398-406.

Hale, M.E. 1955. Phytosociology of corticolous cryptogams in the upland forests of southern Wisconsin. Ecology36: 45-62.

Hanski, I. \& Ovaskainen, O. 2000. The metapopulation capacity of a fragmented landscape. Nature 404: $755-758$.

Harris, G.P. 1970. The ecology of corticolous lichens. 1. The zonation on oak and birch in South Devon. Journal of Ecology 59: 431-439.

Hultengren, S., Pleijel, H. \& Holmer, M. 1997. Ekjättar - historia, naturvärden och vård. Naturcentrum, Uddevalla, SE. (In Swedish.)

Johansson, P. \& Ehrlén, J. 2003. Influence of habitat quantity, quality and isolation on the distribution and abundance of two epiphytic lichens. Journal of Ecology 91: 213-221.

Johansson, P., Rydin, H. \& Thor, G. 2007. Tree age relationships with epiphytic lichen diversity and lichen life-history traits on ash in southern Sweden. Écoscience 14: 81-91.

Kantvilas, G. \& Jarman, S.J. 2004. Lichens and bryophytes on Eucalyptus obliqua in Tasmania: management implications in production forests. Biological Conservation 117: 359-373.

Kenkel, N.C. \& Bradfield, G.E. 1986. Epiphytic vegetation on Acer macrophyllum. a multivariate study of species-habitat relationships. Vegetatio 68: 43-53.

Kuusinen, M. 1994. Epiphytic lichen diversity on Salix caprea in old-growth southern and middle boreal forests of Finland. Annales Botanici Fennici 31: 77-92.

Levins, R. 1969. Some demographic and genetic consequences of environmental heterogeneity for biological control. Bulletin of the Entomological Society of America 15: 237-240.

Lindblom, L. \& Måreby, J. 1989. Igenväxningens inverkan på lavfloran på ekstammar. Graphis Scripta 2: 88-91 (The effects of overgrowing on the lichen flora on oak stems. In Swedish with an English abstract).

Löbel, S., Snäll, T. \& Rydin, H. 2006. Species richness patterns and metapopulation processes - evidence from epiphyte communities in boreo-nemoral forests. Ecography29: 169-182.

Loppi, S. \& Frati, L. 2006. Lichen diversity and lichen transplants as monitors of air pollution in a rural area of central Italy. Environmental Monitoring and Assessment 114: 361-375.

Moe, B. \& Botnen, A. 2000. Epiphytic vegetation on pollarded trunks of Fraxinus excelsior in four different habitats at Grinde, Leikanger, western Norway. Plant Ecology 151: 143-159.

Nitare, J. 2005. Signalarter. Indikatorer på skyddsvärd skog. Flora över kryptogamer. 3rd. ed. Skogsstyrelsen, Jönköping, SE. (Indicator species for assessing the nature conservation value of woodland sites: a flora of selected cryptogams. In Swedish, with an English summary).

Ranius, T., Antonsson, K., Jansson, N. \& Johannesson, J. 2001. Inventering och skötsel av gamla ekar i Eklandskapet söder om Linköping. Fauna och Flora 96: 97-107 (Inventories and management of old oaks in an area south of Linköping, Sweden. In Swedish, with an English summary).

Rose, F. 1976. Lichenological indicators of age and environmental continuity in woodlands. In: Brown, D.H., Hawksworth, D.L. \& Bailey, R.H. (eds.) Lichenology: Progress and problems, pp. 279-307. Academic Press, London, UK.

Rydberg, H. 1997. Knappnålslavar på gamla ekar i Södermanland - Status och naturvårdsåtgärder. Svensk Botanisk Tidskrift 91: 39-57 (Caliciales lichens on old oaks in Södermanland, Sweden. In Swedish, with an English summary).

Santesson, R., Moberg, R., Nordin, A. \& Tønsberg, T. 2004. Lichen-forming and lichenicolous fungi of Fennoscandia. Museum of Evolution, Uppsala University, Uppsala, SE.

Snäll, T., Ribeiro, P.J. \& Rydin, H. 2003. Spatial occurrence and colonisations in patch-tracking metapopulations: local conditions versus dispersal. Oikos 103: 566-578.

Snäll, T., Ehrlén, J. \& Rydin, H. 2005. Colonization-extinction dynamics of an epiphyte metapopulation in a dynamic landscape. Ecology86: 106-115.

Sokal, R.R. \& Rohlf, F.J. 1995. Biometry. 3rd. ed. W.H. Stokes, M.A. \& Smiley, T.L. 1968. An introduction to tree-ring dating. University of Chicago Press, Chicago, IL, US

Thomas, J.A., Bourn, N.A.D., Clarke, R.T., Stewart, K.E., Simcox, D.J., Pearman, G.S., Curtis, R. \& Goodger, B. 2001. The quality and isolation of habitat patches both determine where butterflies persist in fragmented landscapes. Proceedings of the Royal Society of London Series B 268: 1791-1796. 
Thor, G. \& Arvidsson, L. (eds.) 1999. Rödlistade lavar i Sverige. Artfakta. Artdatabanken, SLU, Uppsala, SE. (Swedish Red Data book of lichens).

Uliczka, H. \& Angelstam, P. 1999. Occurrence of epiphytic macrolichens in relation to tree species and age in managed boreal forest. Ecography22: 396-405. 
Table 1. Characteristics of the oak (Quercus robur) trees studied at three sites in southeast Sweden (average values and minimum-maximum range). Percentage of the trees on which the target species occurred. Red List categories according to Gärdenfors (2005) are given in parentheses. VU = vulnerable, NT = near threatened, LC = least concern.

$\begin{array}{llll}\text { Brokind } & \text { Bjärka-Säby } & \text { Sundsbro } & \\ N & 55 & 53 & 57 \\ \text { Age } & 242(25-478) & 225(17-457) & 211(26-455) \\ \text { Bark crevice depth (mm) } & 37(2-89) & 34(2-73) & 35(2-101) \\ \text { Diameter (cm) } & 99(10-199) & 80(12-166) & 82(12-202) \\ \text { Shading } & 0.64(0-2) & 0.98(0-2) & 0.89(0-2) \\ \text { Calicium adspersum(LC) } & 55 \% & 40 \% & 49 \% \\ \text { Caloplaca lucifuga (NT) } & 4 \% & 2 \% & 4 \% \\ \text { Chaenotheca phaeocephala (LC) } & 51 \% & 64 \% & 49 \% \\ \text { Chrysothrix candelaris (LC) } & 85 \% & 85 \% & 82 \% \\ \text { Cliostomum corrugatum(NT) } & 36 \% & 34 \% & 25 \% \\ \text { Lecanographa amylacea (VU) } & 7 \% & 2 \% & 0 \% \\ \text { Schismatomma decolorans (NT) } & 5 \% & 0 \% & 2 \% \\ \text { Sclerophora coniophaea (NT) } & 5 \% & 0 \% & 2 \%\end{array}$


Table 2. Characteristics measured (a) at individual tree level and (b) at $10 \mathrm{~cm} \times 10 \mathrm{~cm}$ sample plots evenly distributed on oak (Quercus robur) trunks. All variables that represented proportions were arcsine-square root transformed.

\begin{tabular}{|c|c|c|c|}
\hline $\begin{array}{l}\text { Characteristic } \\
\text { a. Trees }(n=165)\end{array}$ & Unit & Description & Mean $(\min -\max )$ \\
\hline Age & years & Age estimated from increment cores and eq. (1) & $226(17-478)$ \\
\hline Bark crevice depth & $\mathrm{mm}$ & Depth of the deepest bark crevice on the trunk up to $2 \mathrm{~m}$ & $36(2-101)$ \\
\hline Cover of bushes & $\%$ & $\begin{array}{l}\text { Proportion of the trunk surface up to } 2 \text { m covered by shrubs } \\
\text { close to the trunk (arcsine-square root transformed) }\end{array}$ & $11(0-100)$ \\
\hline Diameter & $\mathrm{cm}$ & Trunk diameter $1.3 \mathrm{~m}$ above ground & $87(10-202)$ \\
\hline Shading & & $\begin{array}{l}\text { The vertical projection of foliage around the tree: }<25 \%(0) \text {, } \\
25 \%-75 \% \text { (1) or }>75 \%(2)\end{array}$ & $0.84(0-2)$ \\
\hline $\begin{array}{l}\text { Stem inclination } \\
\text { Tree damage }\end{array}$ & o & $\begin{array}{l}\text { Inclination of the centre of the trunk } 0 \text { to } 2 \mathrm{~m} \text { from the ground } \\
\text { Tree condition: healthy }(1 ;<5 \text { dead branches), damaged ( } 2 \text {; } \\
<40 \% \text { of the crown damaged), dying ( } 3 ;>40 \% \text { of the crown } \\
\text { damaged), or dead (4) }\end{array}$ & $4(0-22)$ \\
\hline Trunk damage & & Hollows or exposed wood up to 2 m present (1) or absent (0) & $0.25(0-1)$ \\
\hline \multicolumn{4}{|c|}{ b. Plots ( $n=600$ on 30 trees) } \\
\hline Bark crevice depth & $\mathrm{mm}$ & Depth of the deepest bark crevice in the plot & $31(0-86)$ \\
\hline Bryophytes $^{1}$ & $\%$ & Cover of bryophytes (arcsine-square root transformed) & $13(0-100)$ \\
\hline Connectivity & & $\begin{array}{l}\text { Number of neighbouring sample plots in which the species was } \\
\text { present. Neighbouring plots were defined as the closest three or } \\
\text { four plots on the trunk in all four directions. }\end{array}$ & $(0-4)$ \\
\hline Cover of bushes & & $\begin{array}{l}\text { Sample plots covered (1) or not covered (0) by shrubs close to } \\
\text { the trunk }\end{array}$ & $0.08(0-1)$ \\
\hline Height & $\mathrm{m}$ & $0.5,1.5,2.5,3.5$ or $4.5 \mathrm{~m}$ above ground & $2.5(0.5-4.5)$ \\
\hline Southfacing & & $\mathrm{N}(=0), \mathrm{E}$ or $\mathrm{W}(=1)$, or $\mathrm{S}(=2)$ & $1(0-2)$ \\
\hline Macrolichens ${ }^{2}$ & $\%$ & Cover of macrolichens (arcsine-square root transformed) & $3(0-60)$ \\
\hline Shading & $\%$ & $\begin{array}{l}\text { Projection of foliage in a quarter of a sphere (in the direction } \\
\text { of the sample plot, from the horizon to the zenith) } \\
\text { (arcsine-square root transformed) }\end{array}$ & $90(52-98)$ \\
\hline Stem inclination & o & $\begin{array}{l}\text { Inclination in the middle of the plot (negative or positive, i.e. } \\
\text { directed 'downwards' or 'upwards', respectively) }\end{array}$ & $3(-51-48)$ \\
\hline
\end{tabular}

${ }^{1}$ The dominant species were Hypnum cupressiforme and Leucodon sciuroides,

2 The dominant species were Evernia prunastri, Parmelia sulcata and Ramalina spp. 
Table 3. Model coefficients and associated $p$-values for relationships between occurrence at tree level (presence, 1 or absence, 0 ) of each study species and tree characteristics in multiple logistic regression models constructed by removing variables with $p>0.05 . n=165$ oaks.

\begin{tabular}{|c|c|c|c|c|c|}
\hline Species & Age & Bark crevice depth & Diameter & Shading & Stem inclination \\
\hline Calicium adspersum & $0.013 * * *$ & & & & \\
\hline Caloplaca lucifuga & & & & & \\
\hline Chaenotheca phaeocephala & $0.009 * * *$ & & & & \\
\hline Chrysothrix candelaris & & $-0.224^{*}$ & $0.280 * * *$ & $2.560 * *$ & $-0.225 *$ \\
\hline Cliostomum corrugatum & $0.008 * *$ & $0.080 * * *$ & & & \\
\hline Lecanographa amylacea & & & $0.038 * *$ & & \\
\hline
\end{tabular}

*, $p<0.05 ; * *, p<0.01 ; * * *, p<0.001$. 

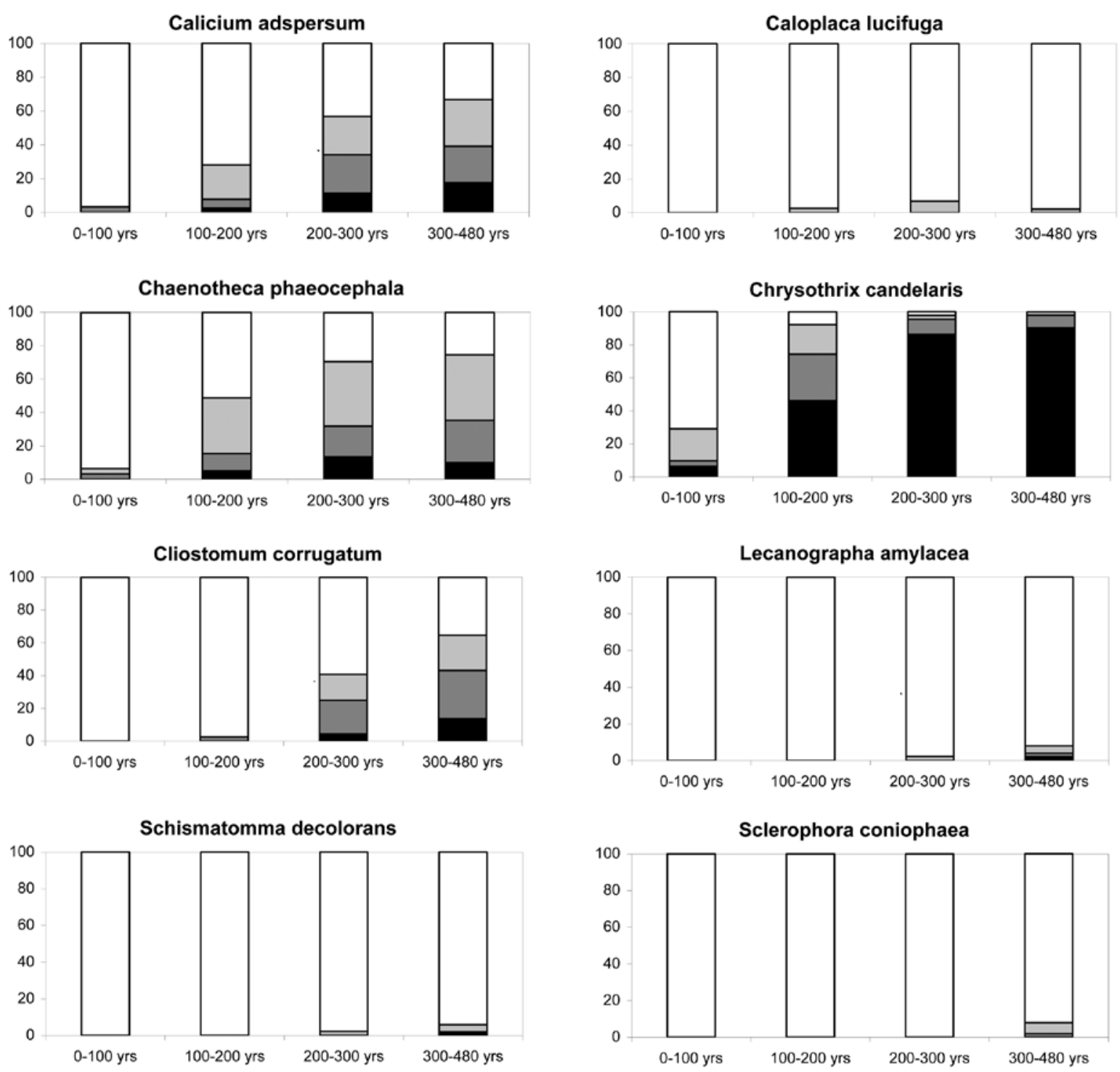

Fig. 1. Frequency of occurrence (\%) of crustose lichen species in relation to tree age. White = absence; light grey $=<1 \mathrm{dm} 2$; dark grey $=1-5 \mathrm{dm} 2$; black $=>5 \mathrm{dm} 2 . n$-value: 31 (0-100 years), 39 (100-200 years), 44 (200-300 years) and 51 (300-480 years). Data from Quercus robur in southeast Sweden. 
Table 4. Statistically significant $(p<0.05)$ Spearman correlation coefficients between tree variables. $n=165$.

Bark crevice depth $0.851^{* * *}$

Age Bark crevice depth Cover of bushes Diameter Shading Stem damage Stem inc.

Cover of bushes

Diameter

$0.878 * * * 0.893 * * *$

Shading $\quad-0.241 * *-0.289 * * *$

Stem damage

$0.338 * * * 0.339 * * *$

$-0.384 * * *$

Stem inclination

Tree damage

$0.623^{* * *} 0.601^{* * *}$

$0.557 * * *$

$0.442 * * *$

$0.218^{* *}$

$*=p<0.05 ; * *=p<0.01 ; * * *=p<0.001$. 
Table 5. Model coefficients and $p$ values for relationships between occurrence (presence, 1 or absence, 0 ) in sample plots on oak trunks and sample-plot characteristics, assessed by multiple logistic regression models constructed by removing variables with $p>0.05 . n=600$ (30 oaks, 20 plots on each trunk).

\begin{tabular}{|c|c|c|c|c|c|c|c|}
\hline & Bark crevice depth & Bryophytes & Connectivity & Stem inclination & Macrolichens & South facing & Tree \\
\hline Calicium adspersum & $0.042 * *$ & $-3.50 * * *$ & 0.360 & & $2.81^{*}$ & $-0.925^{* * *}$ & $* *$ \\
\hline Chaenotheca phaeocephala & & $-3.07 * * *$ & 0.363 & $-0.029 *$ & & & $*$ \\
\hline Chrysothrix candelaris & $0.037 * * *$ & $-3.24 * * *$ & 0.121 & & & $-0.400^{*}$ & $* *$ \\
\hline Cliostomum corrugatum & $0.040 * *$ & $-3.53^{* * *}$ & 0.349 & & & & \\
\hline
\end{tabular}

$*=p<0.05 ; * *=p<0.01 ; * * *=p<0.001$. 


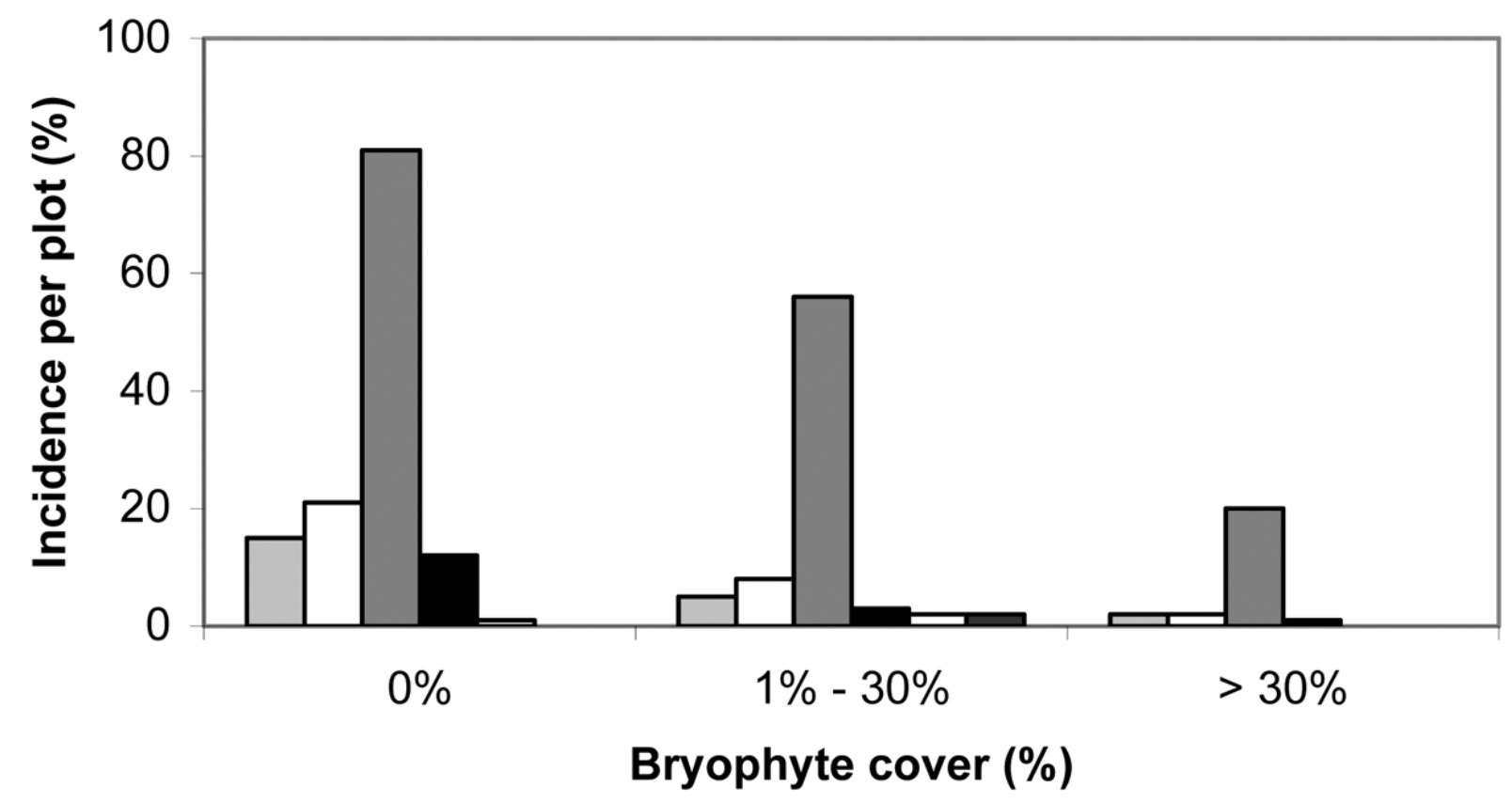

Fig. 2. Incidence per plot of six crustose lichen species in relation to bryophyte cover. Species (bars from left to right): Calicium adspersum, Chaenotheca phaeocephala, Chrysothrix candelaris, Cliostomum corrugatum, Lecanographa amylacea and Schismatomma decolorans. Number of plots $(0 \%)=385$, (1 \% - $30 \%)=117$, and $(>30 \%)=98$. 


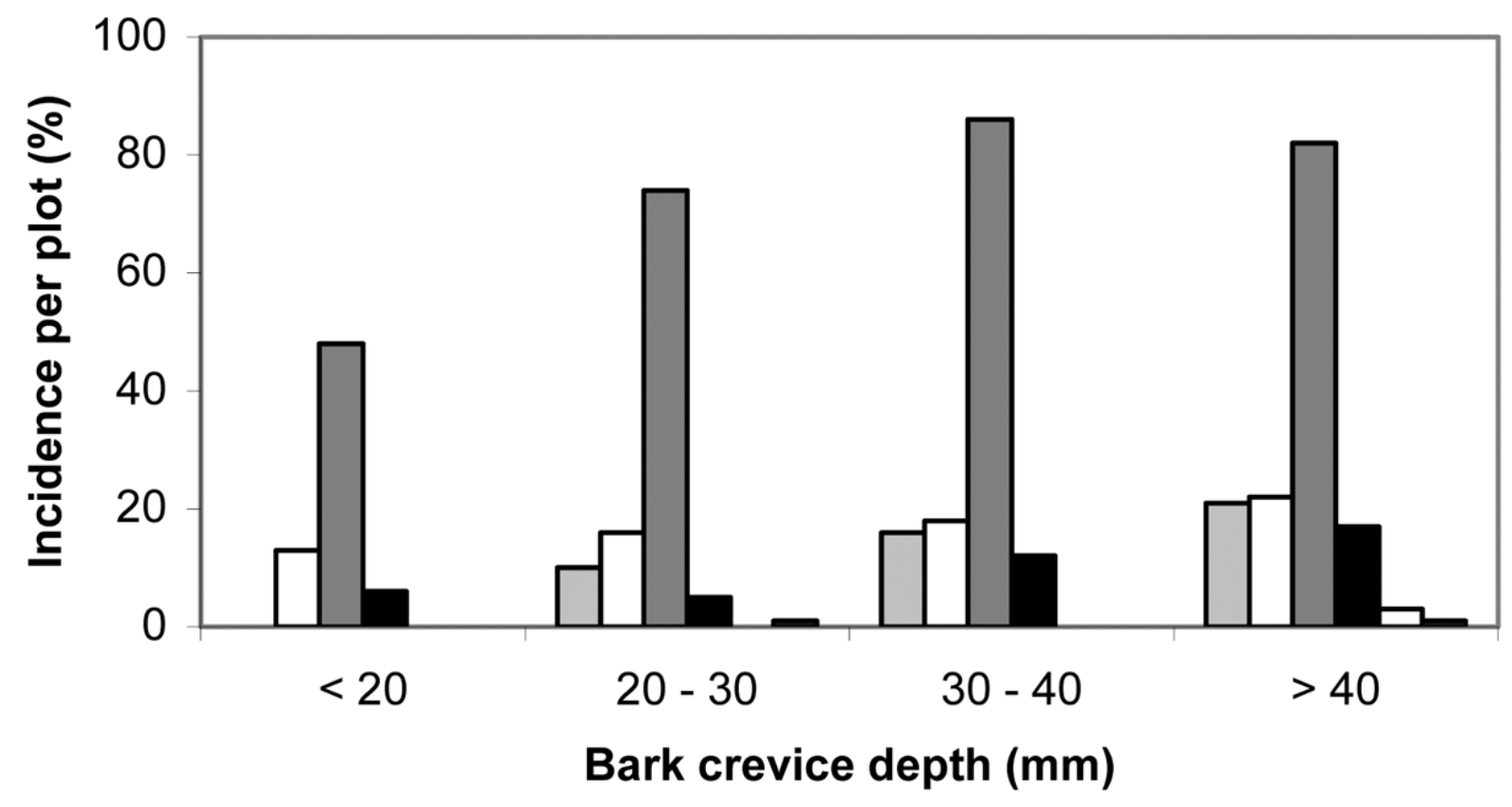

Fig. 3. Incidence per plot of six crustose lichen species in relation to bark crevice depth. Species (bars from left to right): Calicium adspersum, Chaenotheca phaeocephala, Chrysothrix candelaris, Cliostomum corrugatum, Lecanographa amylacea and Schismatomma decolorans. $n(<20 \mathrm{~mm})=85,(20-30 \mathrm{~mm})=155,(30-40 \mathrm{~mm})=$ 121 , and $(>40 \mathrm{~mm})=141$. Plots with $>30 \%$ bryophyte cover are excluded, regarded as unsuitable for the species (see Fig. 2). 
Table 6. Statistically significant $(p<0.05)$ Spearman correlation coefficients between characteristics of sample plots on oak trunks. $n=600$ (30 oaks, 20 plots on each trunk).

\section{Bark crevice depth}

Bryophytes
Cover of bushes

Height $(\mathrm{m}) \quad-0.100^{*}$

Inclination $\quad-0.159^{* * *}$

Macrolichens

Shading

Southfacing $-0.313^{* * *}$
Bark crevice depth Bryophytes Cover of bushes

Height (m) Inclination Macrolichens

Shading

$\begin{array}{ll}-0.100 * & \\ -0.159 * * * & 0.395^{* * *} \\ & 0.149 * * * \\ & 0.089 *\end{array}$

$-0.266^{* * *}$

$0.089 *$

$$
\begin{array}{ll}
-0.234^{* * *} & \\
0.084 * & \\
-0.254 * * * & 0.123 * *
\end{array}
$$

$-0.265^{* * *}$

$*=p<0.05 ; * *=p<0.01 ; * * *=p<0.001$. 


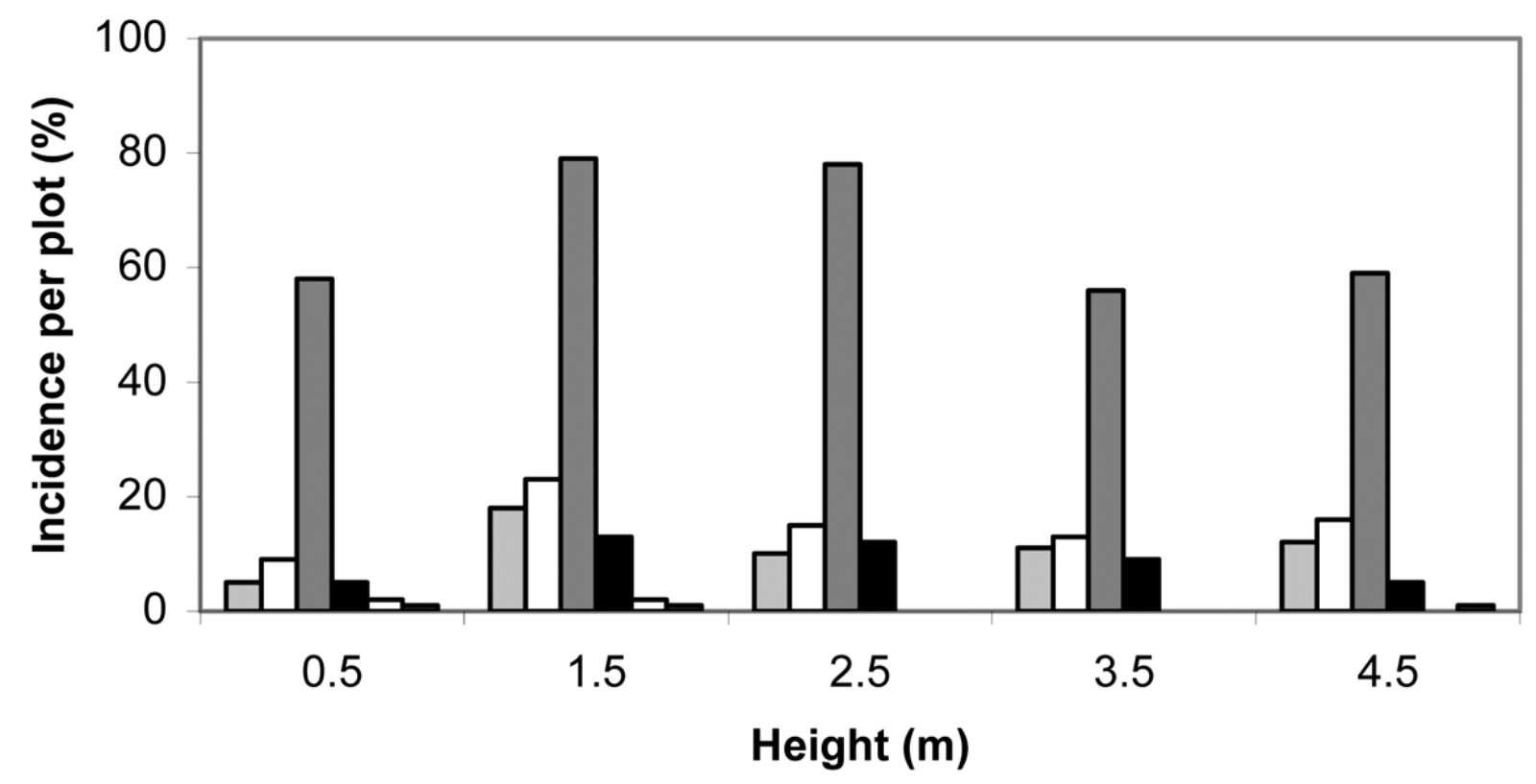

Fig. 4. Incidence per plot of six crustose lichen species in relation to height above ground. Species (bars from left to right): Calicium adspersum, Chaenotheca phaeocephala, Chrysothrix candelaris, Cliostomum corrugatum, Lecanographa amylacea and Schismatomma decolorans. $n=120$ per height level. 